\title{
WHY IS THE DOHA DEVELOPMENT AGENDA FAILING? AND WHAT CAN BE DONE? A COMPUTABLE GENERAL EQUILIBRIUM-GAME THEORETICAL APPROACH
}

\author{
Antoine Bouët and David Laborde
}

T he trade negotiations led under the banner of the Doha Development Agenda (DDA) are complex, as highlighted by the Cancun summit in September 2003 and the Geneva meeting in July 2008. ${ }^{1}$ This last meeting largely confirmed the perception of the DDA as a failure (Economist 2008). In 2012 and 2013, trade officials tried to give a new impulse to Doha negotiations, but in 2015 they were not yet completed even if in December 2013, in Bali, the new WTO director, Roberto Azevêdo, announced the Bali package concerning in particular implementation of trade facilitation. During the Geneva meeting in 2008, Pascal Lamy tried to cut a deal among seven countries (Australia, Brazil, China, the European Union, India, Japan, and the United States). This initiative has been criticized due to the fact that the WTO rules call for consensus. ${ }^{2}$ Another distinctive feature of these negotiations is the emergence of countries' coalitions (such as the G20, the G90, or the G10), which play an active role in the bargaining process. ${ }^{3}$ A new characteristic is also present in the "Aid for Trade" package, which according to the WTO, means further assistance for developing countries "to increase

1 This chapter was originally published in Bouët and Laborde (2010). We thank Jean-Christophe Bureau, Lionel Fontagné, Gaspar Frontini, Tom Hertel, Sébastien Jean, Will Martin, participants of the 2004 Global Trade Analysis Project (GTAP) conference in Washington, DC, and the September 2004 Association Française de Sciences Economiques (AFSE) Congress in Paris, and two anonymous referees who provided comments on an earlier version of this paper.

2 The July 2008 Geneva group was supposed to identify a compromise representing interests well beyond those of group members.

3 The G20 gathers together 20 emerging countries and least developed countries (LDCs), is led by Brazil and India, and also includes China and South Africa. It generally plays an active role in favor of agricultural liberalization. The G90 is a set of 90 poor countries with a more defensive trade strategy aimed to advance pro-poor policies (most African countries are members of this group). The G10 includes 10 countries, mainly from the Organisation for Economic Co-operation and Development (OECD); these include Iceland, Japan, Norway, South Korea (Republic of Korea), Switzerland, and Taiwan, China. The G10 primarily seeks to impede agricultural liberalization. 
their capacity to take advantage of more open markets" (WTO 2016). Some observers, however, describe this initiative as financial compensation for countries that are expected to suffer losses under the agreement (see Stiglitz and Charlton 2006; Evenett 2005b).

The objective of this chapter is to provide a strategic analysis of these negotiations. In particular, we examine whether these trade negotiations can reach a pro-liberalization outcome, and if so, which packages may be approved. If no pro-liberalization outcome is possible, we ask the following questions: Which countries are preventing the achievement of an agreement, and why? Is there any way to change the negotiation rules to achieve a pro-liberalization outcome? How can we explain the creation of coalitions, and do they thwart the success of the negotiations?

Strategic analysis of international trade negotiations is common in the economic literature. Johnson (1953) studies tariff equilibrium between two big countries. In a later work (Johnson 1965) he examines an international trade framework where trading partners exchange reduced production in import-competing sectors for increased production in exporting sectors. Mayer (1981) shows that a domestic conflict of interest may prevent the negotiation of free trade between two big countries. The Prisoners' dilemma is used by Riezman (1982) to show that the outcome of a noncooperative game between big countries is tariff equilibrium. Baldwin and Clarke (1988) analyze the Tokyo Round as a bargaining process between the European Union and the United States, where both trading partners try to minimize an overall welfare loss function. Tyers (1990) identifies policy preferences that are implicit in European and Japanese actual tariff patterns and uses these derived weights and the associated objective function to assess which tariff reforms could be negotiated by both countries. Grossman and Helpman (1995) have demonstrated that trade agreements allow governments to escape the wellknown terms of a trade prisoners' dilemma even when those governments are subject to domestic political pressure. Turning to the precise rules of those agreements, Bagwell and Staiger $(1999,2002)$ have established that reciprocity and nondiscrimination might act as commitments toward efficiency under a broad set of assumptions on the underlying domestic political games.

We think that the strategic context of the DDA is far different from that of previous rounds. The large number of players (from 23 in 1947 up to 160 countries in June 2015) and the diversity of economic situations are especially important considering that the WTO rules call for consensus. More important, while the outcomes of previous rounds were largely expected to be negotiated between the EU and the United States, the number of active 
participants (Australia, Brazil, and India, for example) in the current bargaining process has increased. The immediate question that comes to mind, therefore, is whether these new features explain the stalemate in which these negotiations seem to have been since the second half of 2008. Recent methodological developments allow for a more systematic study of this bargaining process. Thanks to improvements in computation ability, the availability of databases on world macroeconomic variables (for example, the GTAP database; Dimaranan and McDougall 2005) and market access (for example, the MAcMapHS6 database; Bouët et al. 2008), and the development of multicountry and multisector Computable General Equilibrium (CGE) models, it is possible to simulate numerous scenarios of trade reform and evaluate their impacts on each WTO member. This may be done against the economic theories of negotiation developed by Nash (1953), Shapley (1953), and Kalai and Smorodinsky (1975). Hence, the combination of theoretical developments and modeling capacities allows us to model negotiations among numerous countries and regions with microeconomic foundations.

To analyze the potential outcome of the DDA, we use the MIRAGE (Modelling International Relationships in Applied General Equilibrium) model of the world economy and recent databases covering market access and domestic support. ${ }^{4}$ Unlike traditional studies that begin with a particular scenario, we herein study a set of agreements representative of discussions at the time of the beginning of the negotiations. These include 143 trade shocks that are expected to represent the whole set of negotiations. These shocks are studied with the help of the MIRAGE model. Inside the domain defined by all these potential outcomes, the Nash solution, as defined by the theory of axiomatic bargaining, is selected. The Nash solution defines an efficient and rational solution to any bargaining problem.

We find that a pro-liberalization agreement is very difficult to achieve due to the heterogeneity of WTO members. There are, however, several possible solutions. First, the exclusion of small countries improves the efficiency of the negotiation process, regardless of the governments' objectives. Second, the creation of coalitions potentially allows developing countries to act against the solutions selected by rich countries. Third, it may be possible and useful to expand the domain of trade negotiations. Fourth, game theory indicates that side payments may be effective, in that actors can maximize the "size of

4 The MIRAGE model was developed at the Centre d'Etudes Prospectives et d'Informations Internationales (CEPII) in Paris. A full description of the model is available in Decreux and Valin (2007). 
the cake" for their purposes by using side payments to compensate losers and buy the agreement of each player. The chapter first explains our methodology. Next, the economic impacts of all scenarios are broadly characterized. We then apply the theory of cooperative games and introduce three mechanisms for improving the efficiency of the negotiations. We look at the possibility of coalitions, and finally we offer conclusions.

\section{Methodology}

\section{Model and Data}

This study uses the MIRAGE model of the world economy to assess economic consequences of various trade reforms. The MIRAGE model is a multinational multisector CGE model (see Decreux and Valin 2007). In this study the MIRAGE model is used under its static version, with a perfect competition hypothesis and without modeling foreign direct investment. The main purpose of this modeling scenario is to simulate many potential trade reforms and to represent as exhaustively as possible the entire domain of negotiation. We use perfect competition instead of imperfect competition as the latter framework necessitates supplementary data (number of firms, mark-up, and magnitude-of-scale economies) for calibration purposes, which are difficult to gather for many regions. At the same time, this theoretical option can deeply affect the impact of a trade reform (see van Tongeren, van Meijl, and Surry 2001). The use of the static version is also justified by the fact that we are not interested in the dynamics of the reform but only in the long-term impact on various regions.

The first source of data is GTAP6.1 (Dimaranan and McDougall 2005), which provides world macroeconomic accounts and trade flows for the year 2001. Notably, we seek to describe the complexity of the negotiations at the beginning of the process. Of course it would be worthwhile to study whether the current trade features have made the negotiations even more difficult than they were at the beginning of the process. However, we contend that the main reasons for the present stalemate are:

1. the large number of participants with heterogeneous economic and trade characteristics;

2. the dispersion of protection and other distortions across sectors; and

3. the existence of trade preferences and regional agreements that generate preferential access. 
These three features still characterize the world trading system in 2015, even if new policies have been put in place (for example, the US Farm Bills implemented in 2002 and 2008, the Economic Partnership Agreements implemented or still in negotiation, the recent developments in the European Common Agricultural Policies, and so on): in fact, these new policies may further complicate the intricacy of international trade relations. ${ }^{5}$ On the other hand, from 2004 to 2014 the negotiations have focused on narrow issues. Starting with the 2004 July Package, the broad features of the modalities have been defined and the remaining controversial issues are connected more to the flexibilities to be given to rich and developing countries, including sensitive and special products and special safeguard mechanisms. Since they address very particular political economy problems, introducing them into the analytical framework presented here will bring limited insights.

The market access data comes from the MAcMapHS6 version 1 database (Bouët et al. 2008), which measures protection in 2001 and includes all regional agreements and trade preferences existing to this date. A database on bound duties (Bchir, Jean, and Laborde 2006) has also been developed to apply tariff formulae on bound duties instead of applied duties. Accounting for the binding overhang effect is particularly important in the case of developing countries, for which binding overhang is often large. A database on domestic support has also been constructed from OECD's data on the production subsidy equivalent, as the traditional aggregate measure of support (AMS) relies on old world prices data. This database takes into account trends in agricultural policies established by the US Farm Bill in place in 2001 and the CAP Agenda 2000. Existing databases on market access in services (Francois and Hoekman 1999; Hoekman 1996; Kalirajan et al. 2000; Trewin 2000) are incomplete and not reliable enough to be the basis of a systematic analysis of WTO negotiation. In the GTAP database, protection in services is insufficiently assessed. Frequency indexes are much more informative but do not fully account for the complexity of trade barriers in this sector. To cope with this lack of data, we impose a uniform ad valorem tax of 20 percent in all countries and in all business service activities. It is a transaction cost that generates rents for economic agents in the importing country. Since we acknowledge that using a homogenous 20 percent tax on business services is a very crude modeling approach, we present results with and without this modeling element to check how it affects results.

5 Our baseline takes into consideration the US Farm Bill in place in 2001 and the Everything But Arms (EBA) Initiative. 
Our initial expectation is that the heterogeneity of negotiating countries could lead to a DDA failure. Therefore, when selecting the strategy of geographical decomposition to be used for this work, we give priority to analyzing the structural diversity of the various WTO members. Of course, the geographic decomposition is a key element of the methodological design of the study. We think that the main elements that determine a country's stance in the negotiations are (1) the average level of trade-related distortions that affect its imports and its exports; (2) the sector and partner dispersion of its protection; (3) its economic size and dependence on trade; and (4) its product and geographic concentration of imports and exports.

On the basis of the GTAP6.1 database, we select countries that are specific either in terms of trade specialization (Brazil and Argentina [agriculture] versus China and Bangladesh [industry] versus India [services]), or in terms of preferential access received (Bangladesh, which is beneficiary of the Everything But Arms Initiative versus China, India, Indonesia, and Thailand, which are not; Mexico and Canada with their preferential access to the United States versus all other OECD countries), or preferential access given (the EU versus Japan and Australia), or geographic structure of trade flows (all the continents are represented). Another element is the structure of protection, in terms of average level (OECD versus middle-income countries versus low-income countries) and of sector dispersion of protection (the EU, Japan, Korea, Taiwan versus the United States). We also account for the diversity in economic size and dependence on trade (Bangladesh versus China and India, New Zealand and Chile versus the United States and the EU).

Table 3.1 presents the geographic decomposition. Considering the intercountry and inter-region trade and protection, this decomposition captures 95.5 percent of the world tariff revenue (which can be considered as a measure of the global distortion in play) and 71.3 percent of world trade (which is the macroeconomic variable affected by the distortion). ${ }^{6}$ It appears to be a solid basis for our modeling exercise. The sector decomposition focuses on agriculture and identifies 23 sectors, 10 of which are agricultural (Table 3.2). In agriculture, sectors where distortions are large are rice, sugar, cereals nec (not elsewhere classified), livestock and meat, meat products, milk and dairy products. In industry, these are mainly textile and wearing.

6 These calculations have been realized using the MAcMapHS6 database. 
TABLE 3.1 Geographic decomposition

\begin{tabular}{|c|c|c|}
\hline Country or region & GTAP code & Coalition \\
\hline Argentina & $\arg =$ Argentina & G22/Cairns \\
\hline Australia & aus $=$ Australia & Cairns \\
\hline Bangladesh & bgd = Bangladesh & G90 \\
\hline Brazil & bra $=$ Brazil & G22/Cairns \\
\hline Canada & can $=$ Canada & Cairns \\
\hline Chile & chl = Chile & G22/Cairns \\
\hline China & chn = China & G22 \\
\hline $\begin{array}{l}\text { CIS (Commonwealth of Independent } \\
\text { States) }\end{array}$ & $\begin{array}{l}\text { rus }=\text { Russian Federation; } x s u=\text { rest of Former } \\
\text { Soviet Union }\end{array}$ & \\
\hline EFTA (European Free Trade Association) & che $=$ Switzerland; $x$ ef $=$ rest of EFTA & G10 \\
\hline European Union (25 countries) & $\begin{array}{l}\text { aut, bel, dnk, fin, fra, deu, gbr, grc, irl, ita, lux, nld, } \\
\text { prt, esp, swe, cyp, cze, hun, mlt, pol, svk, svn, est, } \\
\text { lva, Itu = } 25 \text { countries of the European Union }\end{array}$ & \\
\hline India & ind = India & G22 \\
\hline Indonesia & idn = Indonesia & Cairns \\
\hline Japan & jpn = Japan & G10 \\
\hline Republic of Korea; Taiwan & kor $=$ Republic of Korea; twn = Taiwan & G10 \\
\hline Mediterranean Countries & $\begin{array}{l}\text { tur }=\text { Turkey; } \text { xme }=\text { rest of Middle East; } \text { mar }= \\
\text { Morocco; xnf = rest of North Africa }\end{array}$ & G90 \\
\hline Mexico & $\operatorname{mex}=$ Mexico & G22 \\
\hline New Zealand & $\mathrm{nzl}=$ New Zealand & Cairns \\
\hline Rest of Asia & $\begin{array}{l}\text { xea = rest of East Asia; mys = Malaysia; phl= } \\
\text { Philippines; vnm =Viet Nam; xse = rest of Southeast } \\
\text { Asia; Ika =Sri Lanka; xsa = rest of Asia }\end{array}$ & \\
\hline Rest of Central America & $\begin{array}{l}x c a, x c b=\text { Rest of Central America and of the } \\
\text { Caribbean }\end{array}$ & G22 \\
\hline Rest of South America & $\mathrm{xsm}=$ Rest of South America & G22 \\
\hline Rest of the world & $\begin{array}{l}\text { xoc = rest of Oceania; } \mathrm{hkg}=\text { Hong Kong; sgp = } \\
\text { Singapore; xna = rest of North America; col = } \\
\text { Colombia; per = Peru; ven =Venezuela; ury = } \\
\text { Uruguay; xsm = rest of South America; xer = rest of } \\
\text { Europe; alb =Albania; bgr = Bulgaria; hrv = Croatia; } \\
\text { rom = Romania }\end{array}$ & \\
\hline South Africa & $\begin{array}{l}\text { bwa }=\text { Botswana; zaf }=\text { South Africa; } x s c=\text { Rest of } \\
\text { South Africa Custom Union }\end{array}$ & $\begin{array}{l}\text { G90/G22/ } \\
\text { Cairns }\end{array}$ \\
\hline Africa south of the Sahara & $\begin{array}{l}\mathrm{mwi}=\text { Malawi; } \mathrm{moz}=\text { Mozambique; tza = United } \\
\text { Republic of Tanzania; } \text { zmb = Zambia; } \text { zwe = } \\
\text { Zimbabwe; } \mathrm{mdg}=\text { = Madagascar; uga =Uganda; } \\
\text { xss = rest of Africa south of the Sahara }\end{array}$ & G90 \\
\hline Thailand & tha $=$ Thailand & G22/Cairns \\
\hline United States & usa $=$ United States & \\
\hline
\end{tabular}

Source: Authors. 
TABLE 3.2 Sector decomposition

\begin{tabular}{lll}
\hline Sector code & Description & GTAP code \\
\hline Agri_ind & Food products, not elsewhere classified & ofd, vol \\
Bev_Tob & Beverages and Tobacco & b_t \\
Bus_serv & Business services & isr, obs, ofi \\
Cereals nec & Cereals, not elsewhere classified & gro, wht \\
Chim_ind & Chemical industry & crp, p_c \\
Dairy_prod & Milk and Dairy Products & mil, rmk \\
Electronic & Electronic & ome \\
Lvst_Meat & Livestock and Meat & ctl, oap \\
Mach_ind & Equipment goods & omf \\
Meat & Meat products & cmt, omt \\
Metal_ind & Metal industry & fmp, i_s, nfm \\
OthCrop & Other crops, not elsewhere classified & ocr, osd, pfb \\
Othlnd & Other industries & ely, nmm \\
OthPrim & Other primary products & coa, frs, fsh, gas, oil, omn, wol \\
OthServ & Other services & cns, dwe, gdt, osg, ros, trd, wtr, ele \\
Rice & Rice & pcr, pdr \\
Sugar & Sugar & c_b, sgr \\
Textiles & Textile & tex \\
Tran_ind & Transportation industry & mvh, otn \\
Trans_com & Transportation and Telecommunication & atp, cmn, otp, wtp \\
Veg_fruit & Vegetable and Fruit & v_f \\
Wearing & Wearing, apparel & lea, wap \\
Wood_paper & Wood and paper & lum, ppp \\
\hline Sour & &
\end{tabular}

Source: Authors.

Note: See the GTAP website for a full description of GTAP sectors and GTAP code.

\section{The Objective of Trade Negotiators}

A strict definition of national objectives is necessary for analytical purposes. Those objectives have to represent the elements taken into account by negotiators. It leads us to consider four indicators in this study: (1) the Hicksian equivalent variation of the representative agent; (2) real gross domestic product (GDP); (3) maximization of exports; and (4) terms of trade. The Hicksian equivalent indicator has often been adopted in the literature and has robust microeconomic foundations. Also, using this indicator means that consumers' interests are as weighted in the government's objective as producers' interests 
and public receipts. The real GDP is often cited as an objective by negotiators, but it lacks microeconomic foundations. Maximization of exports is a mercantilist objective, frequently quoted by negotiators, and the terms of trade is another mercantilist objective. These objectives appear to be gross approximations, but we limit our analysis to these four objectives as it would be unviable to design a political model adapted to every WTO member. It could be argued that real GDP and welfare are very close objectives. In fact, if trade is initially balanced, the change in Hicksian variation as a share of initial expenditure is the change in nominal GDP deflated by the change in the cost of expenditure. However, trade is not initially balanced in our modeling exercise. Moreover, we define real GDP here by deflating nominal GDP by production prices, and not the cost of expenditure.

Optimizing terms of trade is a key objective and is considered politically important by authors such as Bagwell and Staiger (1999). Terms of trade are usually improved when trading partners liberalize. When only one country liberalizes and others do not, its terms of trade deteriorate, while a country that does not liberalize while others do may experience deterioration of its terms of trade due to its initial free access to foreign markets (such a situation would be an example of eroded preferences). In this sense, optimizing terms of trade can accurately characterize the mercantilist spirit of trade negotiators. It is possible to consider a trade reform wherein all WTO members receive improved terms of trade, in that the WTO does not comprise all countries in the world. Of course, this case is less conceivable given an international organization composed of 153 countries rather than the 23 present at the first negotiation.

\section{Scenarios}

A set of trade shocks is simulated in order to give a fairly correct representation of what could be negotiated under the DDA at the time of the launching of this negotiation and what the fundamental interests of WTO members are. From this point of view, it would not be correct to design numerous scenarios around the last modalities published in 2008, since that would not reflect the real problems associated with these negotiations since the beginning of the process. On the contrary, we have to design scenarios around the main dimensions that were discussed during the first years of the round. Five key dimensions of the negotiation are emphasized through the design of these shocks: (1) the extent to which import duties are cut; (2) the degree of harmonization (progressivity) adopted in the tariff-reduction formulae; (3) the provision of 
special and differential treatment (SDT); (4) global or sector-level negotiation; and (5) a cut in export subsidies.

We consider services, industry (NAMA for nonagricultural market access), agriculture (AMA for agricultural market access), and reduction of export subsidies (Table 3.3). We suppose that liberalization in services takes the form of a reduction by 50 percent in the transaction cost previously defined. As far as industry is concerned, on the one hand, two Swiss formulae are simulated with coefficients $\mathrm{a}=5$ percent and $\mathrm{a}=10$ percent. The agreement may include an SDT in some cases. In the case of SDT, the coefficient of the Swiss formula is doubled for developing countries and tripled for least developed countries (LDCs), implying that market access is improved in those countries to only a reduced extent. Finally, a complete liberalization in the textile-apparel sector is tested. This " 0 for 0 option" is added to a scenario with a 5 percent Swiss formula in other industrial sectors and without SDT. In agriculture, two Swiss formulae are also considered, with less harmonizing coefficients $(\mathrm{a}=$ 15 percent and $\mathrm{a}=30$ percent). SDT is also tested in the same way as for industry. As the EU proposed a linear reduction of import duties, by a 33 percent coefficient, this nonharmonizing formula is simulated. In this case, the coefficient is 25 percent for developing countries, 15 percent for LDCs. Finally, concerning export subsidies, a cut by 75 percent is considered.

In all trade shocks, duties less than 3 percent are annulled. From a global point of view, 143 trade shocks are simulated. To facilitate identification, the following code is adopted (Table 3.3). A trade shock is notified sABCD with $A, B, C$ and $D$ an integer that belongs to $\{0,1,2,3,4,5\}$. For instance, the trade shock s0121 means (see Table 3.3): (1) the status-quo in services; (2) a Swiss formula in NAMA with a 10 percent coefficient and no SDT; (3) a Swiss formula in AMA with a 25 percent coefficient and with SDT; and (4) a reduction in export subsidies by 75 percent.

\section{Assessing Economic Impacts of Potential Reforms}

The impact of the five modalities on protection applied is shown in Table 3.4 with the split between agricultural sector (AMA) and nonagricultural sector (NAMA).

The trade reforms that maximize world gains in terms of Hicksian equivalent variation or GDP are presented on Table 3.5: s1531 is a liberalization in services, a very harmonizing Swiss formula without SDT in industry and agriculture, with a " 0 for 0 " option in textile and apparel, and a 75 percent 
TABLE 3.3 Definition of scenarios

\begin{tabular}{|c|c|c|c|c|}
\hline \multicolumn{5}{|c|}{ Domain } \\
\hline Indicator & A & B & C & D \\
\hline Value & Services & $\begin{array}{l}\text { NAMA (nonagricultural } \\
\text { market access) }\end{array}$ & $\begin{array}{l}\text { AMA (agricultural } \\
\text { market access) }\end{array}$ & Export subsidies \\
\hline 0 & Status quo & Status quo & Status quo & Status quo \\
\hline 1 & Reduction by $50 \%$ & $a=10 \%$ & $a=25 \%$ & Reduction by $75 \%$ \\
\hline 2 & n.a. & $a=10 \%+$ SDT & $a=25 \%+S D T$ & n.a. \\
\hline 3 & n.a. & $a=5 \%$ & $a=15 \%$ & n.a. \\
\hline 4 & n.a. & $a=5 \%+S D T$ & $a=15 \%+$ SDT & n.a. \\
\hline 5 & n.a. & 0 for 0 & Linear formula + SDT & n.a. \\
\hline
\end{tabular}

Source: Authors.

Note: n.a. $=$ not applicable.

reduction in exports subsidies. It implies the largest increase in world welfare. This optimum is $\mathrm{s} 0531$, when excluding negotiation in services. If the criterion is the augmentation of exports, the best scenario is s1530 under which export subsidies are not cut. These gains are comparable with those obtained in similar studies (Bchir, Fontagné, and Jean 2005): US\$105 billion if the most liberalizing scenario is adopted.

The examination of results implied by each scenario leads to several conclusions.

- A major part of world gains come from agricultural liberalization, due to the high level of initial protection. This confirms conclusions of other studies, like van der Mensbrugghe and Beghin (2004), Francois, van Meijl, and van Tongeren (2005), or Hertel and Keeney (2006).

- Gains coming from liberalizing industry are smaller. In the best case scenario, they add up to US $\$ 14$ billion. It corresponds to a very harmonizing Swiss formula, without SDT and with a "0 for 0" option in textile and apparel. A smaller initial protection explains these limited gains. Moreover, tariff peaks are less frequent.

- Gains are overadditive; the sum of gains coming from elementary shocks is inferior to that derived from the scenario in which all these shocks are combined.

- A cut in export subsidies is all the more fruitful as it is combined with a reduction in agricultural tariffs. 
TABLE 3.4 Impact of various tariff cuts on applied import duties (\%)

\begin{tabular}{|c|c|c|c|c|c|c|c|c|c|c|c|c|}
\hline \multirow[b]{2}{*}{ Country or region } & \multicolumn{2}{|c|}{ Initial level } & \multicolumn{2}{|c|}{ Case 1} & \multicolumn{2}{|c|}{ Case 2} & \multicolumn{2}{|c|}{ Case 3} & \multicolumn{2}{|c|}{ Case 4} & \multicolumn{2}{|c|}{ Case 5} \\
\hline & AMA & NAMA & AMA & NAMA & AMA & NAMA & AMA & NAMA & AMA & NAMA & AMA & NAMA \\
\hline Argentina & 11.8 & 12.7 & 10.6 & 6.9 & 11.7 & 10.0 & 8.8 & 4.3 & 11.0 & 6.9 & 11.8 & 0.0 \\
\hline Australia & 3.1 & 5.4 & 2.2 & 3.0 & 2.2 & 3.0 & 1.9 & 2.1 & 1.9 & 2.1 & 2.2 & 0.0 \\
\hline Bangladesh & 19.4 & 15.7 & 13.4 & 1.8 & 18.8 & 2.2 & 9.5 & 1.5 & 18.1 & 2.2 & 19.3 & 0.0 \\
\hline Brazil & 11.1 & 12.5 & 9.6 & 6.5 & 10.9 & 9.4 & 7.8 & 4.0 & 10.1 & 6.5 & 11.1 & 0.0 \\
\hline Canada & 23.2 & 2.9 & 6.0 & 1.7 & 6.0 & 1.7 & 4.3 & 1.3 & 4.3 & 1.3 & 15.7 & 0.0 \\
\hline Chile & 7.0 & 6.8 & 7.0 & 6.8 & 7.0 & 6.8 & 7.0 & 4.3 & 7.0 & 6.8 & 7.0 & 0.0 \\
\hline China & 23.5 & 7.4 & 9.9 & 3.7 & 12.9 & 4.8 & 7.7 & 2.7 & 10.7 & 3.7 & 18.5 & 0.0 \\
\hline $\begin{array}{l}\text { CIS (Common- } \\
\text { wealth of Indepen- } \\
\text { dent States) }\end{array}$ & 16.9 & 8.8 & 16.8 & 8.8 & 16.9 & 8.8 & 16.8 & 8.8 & 16.9 & 8.8 & 16.9 & 0.0 \\
\hline $\begin{array}{l}\text { EFTA (European } \\
\text { Free Trade } \\
\text { Association) }\end{array}$ & 60.0 & 1.5 & 11.9 & 0.6 & 11.9 & 0.6 & 8.2 & 0.4 & 8.2 & 0.4 & 50.9 & 0.0 \\
\hline $\begin{array}{l}\text { European Union } \\
\text { ( } 25 \text { countries) }\end{array}$ & 24.4 & 2.4 & 7.7 & 1.3 & 7.7 & 1.3 & 5.6 & 0.9 & 5.6 & 0.9 & 17.2 & 0.0 \\
\hline India & 57.2 & 30.0 & 19.8 & 6.9 & 31.1 & 10.4 & 13.8 & 4.5 & 22.5 & 7.0 & 48.6 & 0.0 \\
\hline Indonesia & 11.4 & 6.0 & 5.9 & 3.2 & 6.9 & 3.9 & 4.8 & 2.3 & 6.2 & 3.2 & 9.9 & 0.0 \\
\hline Japan & 49.9 & 1.7 & 11.0 & 0.9 & 11.0 & 0.9 & 7.8 & 0.7 & 7.8 & 0.7 & 43.0 & 0.0 \\
\hline $\begin{array}{l}\text { Mediterranean } \\
\text { countries }\end{array}$ & 28.3 & 7.6 & 12.4 & 5.3 & 14.6 & 5.7 & 10.0 & 4.8 & 12.0 & 5.2 & 26.4 & 0.0 \\
\hline Mexico & 41.1 & 10.4 & 14.2 & 5.3 & 19.5 & 7.6 & 10.7 & 3.5 & 15.6 & 5.3 & 34.3 & 0.0 \\
\hline New Zealand & 2.3 & 2.8 & 1.9 & 2.5 & 1.9 & 2.5 & 1.9 & 1.9 & 1.9 & 1.9 & 2.1 & 0.0 \\
\hline Rest of Asia & 16.0 & 9.6 & 8.2 & 3.4 & 9.3 & 4.1 & 7.5 & 2.9 & 8.6 & 3.5 & 15.4 & 0.0 \\
\hline Rest of world & 5.2 & 1.9 & 3.7 & 1.2 & 3.9 & 1.4 & 3.2 & 1.0 & 3.5 & 1.2 & 4.9 & 0.0 \\
\hline $\begin{array}{l}\text { Rest of Central } \\
\text { America }\end{array}$ & 16.8 & 4.7 & 9.2 & 3.0 & 11.6 & 3.7 & 7.2 & 2.1 & 9.9 & 3.0 & 14.8 & 0.0 \\
\hline $\begin{array}{l}\text { Rest of South } \\
\text { America }\end{array}$ & 15.7 & 11.0 & 11.7 & 8.6 & 13.5 & 9.7 & 9.7 & 7.4 & 12.0 & 8.5 & 15.2 & 0.0 \\
\hline South Africa & 21.8 & 7.3 & 7.9 & 3.1 & 10.1 & 4.3 & 6.2 & 2.0 & 8.6 & 3.1 & 21.6 & 0.0 \\
\hline $\begin{array}{l}\text { South Korea- } \\
\text { Taiwan }\end{array}$ & 41.8 & 7.8 & 11.2 & 3.3 & 11.2 & 3.3 & 8.2 & 2.3 & 8.2 & 2.3 & 29.7 & 0.0 \\
\hline $\begin{array}{l}\text { African countries } \\
\text { south of the Sahara }\end{array}$ & 17.9 & 12.2 & 13.0 & 2.5 & 15.6 & 3.0 & 9.9 & 2.1 & 14.6 & 2.7 & 17.9 & 0.0 \\
\hline Thailand & 27.1 & 11.5 & 14.0 & 3.8 & 19.1 & 5.2 & 10.4 & 2.6 & 15.4 & 3.8 & 23.4 & 0.0 \\
\hline United States & 5.5 & 2.2 & 3.1 & 1.0 & 3.1 & 1.0 & 2.5 & 0.7 & 2.5 & 0.7 & 4.3 & 0.0 \\
\hline
\end{tabular}

Source: MAcMapHS6v1; authors' calculations.

Note: $\mathrm{AMA}=$ agricultural market access; NAMA = nonagricultural market access. Reference group weights. Cases 1 to 5 correspond to the lines in Table 3.3. For example, case 1 combines a Swiss formula with coefficient $a=10 \%$ in NAMA and a Swiss formula with coefficient $a=25 \%$ in AMA. 
TABLE 3.5 World optimum

\begin{tabular}{lll}
\hline Category & With liberalization in services & Without liberalization in services \\
\hline Optimal scenario & s1531 & s0531 \\
Equivalent variation & US $\$ 105.05$ billion or $0.33 \%$ & US $\$ 93.8$ billion or $0.29 \%$ \\
Real GDP & US $\$ 127.21$ billion or $0.41 \%$ & US $\$ 114.99$ billion or $0.37 \%$ \\
\hline
\end{tabular}

Source: Authors' calculation.

Note: $\mathrm{s} 1531$ implies liberalization in services (1), the strongest liberalization $(\mathrm{a}=5$ percent) in NAMA including the 0 for 0 in textile and wearing (5), the strongest liberalization ( $a=15$ percent) in AMA (3), and the reduction of export subsidies. $\mathbf{5} 0531$ is the same scenario without services liberalization.

Figure 3.1 shows each scenario according to two characteristics: the unweighted average welfare gain in percentage of initial real income (horizontal axis), and the standard error of the welfare gains in the countries/regions (vertical axis). In the lower left corner of Figure 3.1, we see a set of 47 trade reforms characterized by negative or low unweighted average gains and low standard deviations. One common characteristic of these scenarios is that they yield a relatively small global gain for the world economy (the maximum is US $\$ 41.2$ billion). In contrast, the minimum global gain predicted for the set of trade reforms located in the upper right corner is US $\$ 68.5$ billion. Thus we see that the larger the world gain, the more unequal its distribution.

All of the trade reforms in the lower left corner of the figure are characterized not only by relatively low global gains for the world economy but also by relatively small standard deviations and small unweighted average gains. Reforms leading to negative unweighted average gains are projected to hurt many countries/regions through losses and/or hurt some countries with large relative losses. All of these reforms lack liberalization in agriculture or include a linear tariff reduction in this sector. The distribution of welfare gains varies according to the modalities of each liberalization scenario. For instance, while generating the same increase in world welfare (US $\$ 14$ billion - that is, a growth rate of 0.04 percent), the scenarios of agricultural liberalization under a linear formula (s0050) or a large industrial liberalization (s0500) give contrasting pictures in terms of distribution. In the first case, total real income gain is more evenly shared out among players (whatever their economic size), the percentage of unweighted average gain is greater than the world gain, and the standard deviation is somewhat low. In the second case, industrial liberalization benefits the richest countries/regions, such that the percentage of unweighted average gain is negative, while the world gain is positive. The standard deviation is about fourfold higher. 
FIGURE 3.1 Distribution of scenarios by unweighted global average and standard deviation of country gains

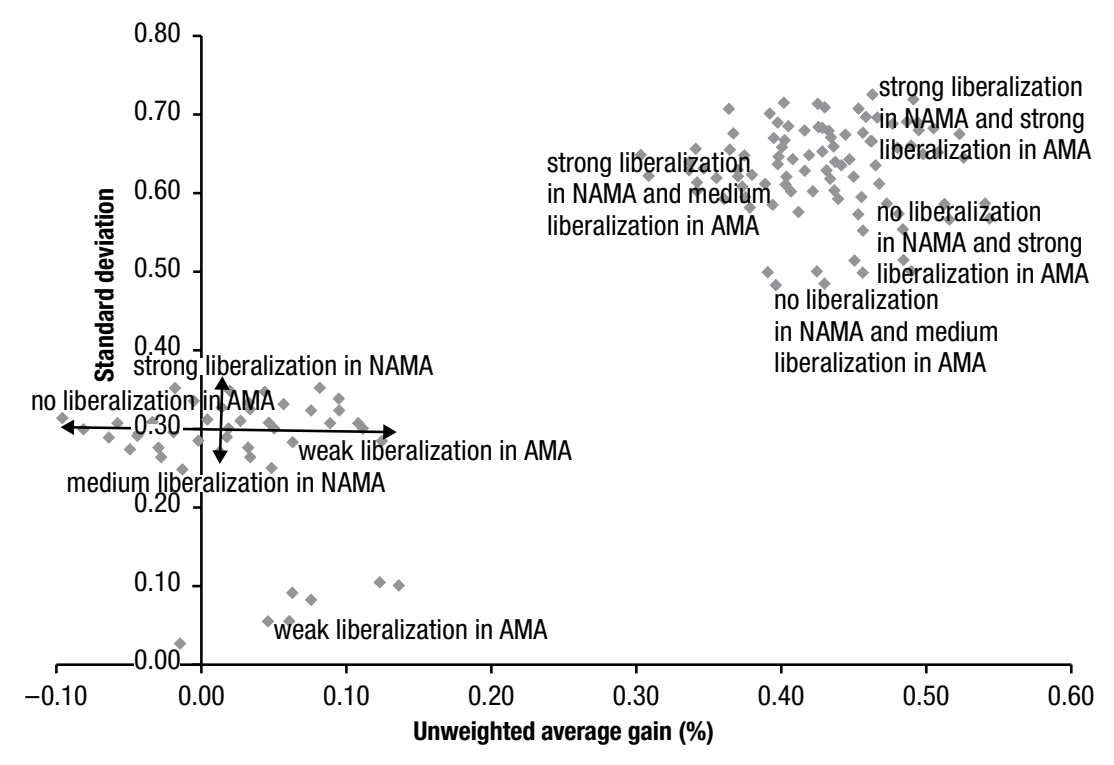

Source: Authors' calculation.

Note: $\mathrm{AMA}=$ agricultural market access; NAMA = nonagricultural market access.

Conversely, all reforms located in the upper right corner of the figure are characterized by a Swiss formula in agriculture, with or without SDT. For all scenarios in the upper right corner of the figure where a Swiss formula is applied on agricultural tariffs, the standard deviation of gains is high, but the unweighted average gain (in percentage) is greater than the global gain for the world economy, implying that these reforms are supported by numerous countries/regions and large countries/regions do not capture most of the gains.

The uneven distribution of the gains is understandable if we consider that the main effects are driven by agricultural liberalization. The cost of protection is quadratic for importing countries/regions. Therefore, we expect the gains to be concentrated in regions where the distortions were initially high. Also, for exporters, two complementary effects are in play, particularly for agricultural liberalization. First, the elimination of tariff peaks creates strong losses for exporters who initially enjoyed preferential access but strong gains for nonpreferred exporters; in this sense, developing countries/regions have contrasting interests. Furthermore, if agricultural liberalization drives the 
majority of the gains, such gains will be concentrated in countries/regions with stronger comparative advantages in this sector (for example, the Cairns Group). Second, in addition, the terms of trade will affect food prices, thereby creating opposite effects on net importers and net exporters of food products. Thus liberalization of industry alone yields an unfair distribution of gains, while liberalization of agriculture alone confers large gains to numerous countries/regions, but these are more unequally distributed. Combining the two options increases the size of the cake, but with an even more unequal distribution (s1530). Therefore, agricultural liberalization is crucial to make the game politically acceptable.

\section{Modeling the Bargaining Process}

Based on game theory, this section describes trade negotiations as a cooperative bargaining process between players. The Nash solution is presented according to several hypotheses about bargaining powers.

\section{The Nash Solution}

The Nash solution is characterized by the following features: the outcome is individually rational (no player is losing compared to the pre-negotiation situation, called the threat point); the outcome is Pareto-optimal (there is no negotiable outcome unanimously preferred); the outcome may be democratic or may reflect a given distribution of power between players (bargaining powers); unlike other axiomatic approaches (egalitarian solution, utilitarian solution, Kalai Smorodinsky solution), the Nash solution fulfils a set of other properties: independence of irrelevant alternatives, independence to a change of units, weak Pareto constraint, symmetry (Mas-Colell, Whinston, and Green 1995).

The Nash solution should not be confused with the concept of Nash equilibrium: (1) the Nash equilibrium applies to noncooperative games and states that the outcome of a game where players do not cooperate is a situation where nobody has any interest to change his or her strategy as long as all other players do not change their own strategy; (2) the Nash solution applies to cooperative games and states that the issue of a negotiation should be individually rational and Pareto-optimal, as just defined. Let us consider that the trade negotiation is a bargaining process between 25 zones on 143 potential outcomes. Let $\mathrm{W}_{0}{ }^{\mathrm{m}}$ be the region $m$ 's initial "payment" in the case nonagreement is reached, $\mathrm{W}^{\mathrm{m}}(\mathrm{s})$ its payment when the outcome $s$ is adopted. $S$ is the set of 
the 143 feasible outcomes. We assume that in case of failure of the bargaining game, the outcome (that is, the threat point) is the status quo-that is, $\mathrm{W}^{\mathrm{m}}(\mathrm{s})=\mathrm{W}_{0}{ }^{\mathrm{m}}, \forall \mathrm{m}$. However, we can also imagine other cases, as follows:

1. Countries/regions start trade wars, increasing their applied duties to the maximum allowed by their bound duties (or even further). This alternative would require us to model and solve the Nash noncooperative game across the 25 countries/regions.

2. Countries/regions decide to negotiate preferential agreements. In this case, we would have to define an optimal trade agreement for each of the 25 countries/regions with any combinations of the 24 other countries/regions, as well as potential agreements with third parties.

These two alternatives would require strenuous calculations that are beyond the scope of the current analysis. Here we seek to understand, within a simple framework, the stalemate in which the trade negotiations have been stalled since 2001. Bouët and Laborde (2010) investigate the potential outcome of Doha Development Agenda (DDA) failure, but the alternative scenarios they used are ad hoc and inconsistent with the game-theory approach discussed herein.

\section{The Nash Solution without Bargaining Power}

In a first stage, we consider that all regions $m$ participate in negotiations and have an identical bargaining power, whatever their geographical, population, and economic size are. ${ }^{7}$ The Nash solution is:

$$
\begin{aligned}
& s^{*} \in \operatorname{Arg}_{s \in S} \operatorname{Max} G(s)=\prod_{m}\left(W^{m}(s)-W_{0}^{m}\right) \\
& \text { with } W^{m}\left(s^{*}\right)-W_{0}^{m} \geq 0, \forall m
\end{aligned}
$$

Condition 2 ensures that the solution will be individually rational.

Table 3.6 shows the different Nash solutions according to the objective adopted by governments and to the negotiation rule defined by equations 1 and 2. The first row gives the Nash solutions when the 25 zones have identical bargaining power, the second row when each country has the same power (democratic weights-see next subsection), and the third row when zones have

\footnotetext{
7 The objective function defined by (1) is a product of regions' changes in welfare; each element can be weighted either by the population of the region, the number of countries composing the region, or economic size of the region (see next subsection). If we do not weigh these differences, regions have identical bargaining power.
} 
TABLE 3.6 Nash solutions of the cooperative game

\begin{tabular}{lcccc}
\hline Category & $\begin{array}{c}\text { Equivalent } \\
\text { variation }\end{array}$ & Real GDP & Exports & $\begin{array}{c}\text { Terms of } \\
\text { trade }\end{array}$ \\
\hline 1 region, 1 voice & $s 1000$ & $s 1520$ & $s 1530$ & No solution \\
1 country, 1 voice & $s 1000$ & $s 1510$ & $s 1530$ & No solution \\
Economic weight & $s 1000$ & $s 1551$ & $s 1530$ & No solution \\
\hline
\end{tabular}

Source: Authors' calculation.

Note: $s 1000$ is a status quo with only a liberalization in services (a net gain for everyone in our modeling). $s 1510$ implies liberalization in services, the strongest liberalization ( $\mathrm{a}=5$ percent) in NAMA including the 0 for 0 option in textile, a moderate liberalization (a $=25$ percent + SDT) in AMA and no export subsidies reduction. s1520 differs from s1510 by the introduction of SDT in agriculture. On the opposite, $s 1530$ is the same scenario but the AMA liberalization is the strongest $(\mathrm{a}=15$ percent, no SDT). s1551 implies liberalization in services, the strongest liberalization $(a=5$ percent) in NAMA including the $0-0$ in textile and wearing, the weakest liberalization (linear reduction) in AMA and the reduction of export subsidies. $\mathbf{s} 0531$ is the same scenario without services liberalization.

bargaining power (see next subsection) proportional to their economic size (GDP-CHELEM database 2001; CEPII 2016). When maximizing exports, the Nash solution represents a very ambitious degree of liberalization (s1530) that benefits all players. Optimizing terms of trade is not a sustainable objective, as this objective features a purely mercantilist world where international liberalization is a constant-sum game and where no Paretian improvement is feasible. In our study, the only possible solution under this objective would be a situation in which all WTO members agree on a reform that improves their terms of trade while deteriorating those of non-WTO members. When maximizing equivalent variation, the outcome is the status quo, except for liberalization of services, which gives every player a welfare gain. Considering that our modeling of services is relatively limited, we can focus on the result without services. In this case, negotiation reaches a stalemate. If governments maximize GDP, it is likely that industry will be hugely liberalized but market access in agriculture will be only slightly improved.

As far as the objective of equivalent variation is concerned, Bangladesh clearly plays a key role in trade negotiations, as this country does not see improvement of its equivalent variation under numerous scenarios, due to deterioration of terms of trade and erosion of preferential margins. This illustrates the position of numerous developing countries/regions that have been granted significant preferences in rich and large markets and are highly specialized in a few products. Thus our results suggest that the position of such countries forms the underlying basis for the stalemate of trade negotiations. In the absence of bargaining power, each player has the same influence. 
However, our definition of a player follows the countries/regions modeled herein, meaning that our disaggregation scheme introduces a bias into the structure of the game. By introducing bargaining power based on measurable country/region features, we can correct for the arbitrary choices inherent in our disaggregation.

\section{The Nash Solution with Bargaining Power}

The cooperative game theory allows for taking into account bargaining powers. It is possible to introduce differentiated bargaining powers in the Nash axiomatic approach. We modify equation 1 by weighting each player's surplus by $\alpha_{\mathrm{m}}$. The Nash solution is given by:

$$
s^{*} \in \operatorname{Arg}_{s \in S} \operatorname{Max} G(s)=\prod_{m}\left(W^{m}(s)-W_{0}^{m}(s)\right)^{\alpha_{m}}
$$

under the same individual rationality constraint expressed by equation (2).

Two alternative weights are considered:

- $\alpha_{\mathrm{m}}$ equals the number of voices at WTO for each zone (1 voice for United States, the European Union, 2 for the Korea/Taiwan zone, 11 for the Mediterranean countries, and so on). This weighting structure is qualified as a democratic system. ${ }^{8}$

- $\alpha_{\mathrm{m}}$ equals the share of the zone in the world GDP. This is the economic power.

Several elements justify giving larger countries a larger bargaining power: (1) multilateral trade negotiation is a bargaining process about market access, and opening the access to large and rich countries is a real priority for all players; (2) big countries have a strong bargaining power since their threat of retaliation is potentially detrimental; (3) big countries have a higher capacity to understand the impact of the various reforms, and they can more easily influence other WTO members on nontrade issues.

The last two rows of Table 3.6 present the results when we use these weights. Only the Nash solution under real GDP criterion is modified when weights are included. In a democratic context, the same solution is adopted, except that it does not include SDT in agriculture. This option has a restrictive impact on South-South trade. When they have a greater decisional power, it is abandoned. On the contrary, when an economic weighting

"Democratic" must be interpreted as a relative concept. 
system is adopted, the s1551 is agreed. This is clearly a compromise between the European Union, Japan, and other industrialized countries. The United States maximizes GDP when s1500 — that is, large openness of industry and services-is adopted. If exports and GDP are not consistent objectives for trade negotiators, the main conclusion of this section is that a status quo is highly probable. In the next subsections, three ways out are considered: the exclusion of some players, the implementation of side payments, and the extension of the domain of negotiation.

\section{Excluding Some Players}

A key reason for the Doha stalemate is obviously the number of negotiating members, which adds constraints to the bargaining program. As a consequence, a solution would be to exclude some members from the negotiating process. Several points support this view: (1) trade negotiation between more than 150 countries is an extremely difficult task as countries' preferences are quite different; (2) trade negotiations require human and technical resources, which only rich countries have; (3) an interpretation of the current situation, when considering the fact that neither LDCs nor small and vulnerable economies (SVEs) have to liberalize, is that they are not officially excluded from the negotiation but have no obligations (so this situation is very close to an exclusion of these countries from the negotiation process); (4) observers often describe past trade negotiations as a bargaining process between a few rich countries (see, for example, the Blair House agreement between the EU and the United States; Messerlin 1995).

To go further, we examine how the exclusion of poor countries-that is, eliminating some of the $m$ players of the optimization program, affects the negotiation. Until the end of this chapter we call $I R$-set the set of scenarios that respect the individual rationality constraint in each program (see equation 2). Table 3.7 indicates the number of solutions in the IR-set, according to various degrees of exclusion of poor countries (the criterion being a share in world GDP). For example, when the equivalent variation is the objective of all negotiators, excluding countries the GDP of which is less than 2 percent of the world GDP implies that the IR-set is 59 instead of 1 . Excluding countries always expands the IR-set of the game. When terms of trade are the objective, exclusion has to be large: the 4 percent threshold implies that India does not take part in the bargaining process such that some agreements may be reached: s1311 with economic weights, s1351 in other cases. When negotiators 
TABLE 3.7 Cardinal of the set of feasible and individually rational (IR) scenarios when player exclusion is allowed

\begin{tabular}{lcccc}
\hline Exclusion threshold & $\begin{array}{c}\text { Equivalent } \\
\text { variation }\end{array}$ & Real GDP & Exports & $\begin{array}{c}\text { Terms of } \\
\text { trade }\end{array}$ \\
\hline None & 1 & 31 & 39 & 0 \\
$<2 \%$ of world GDP & 59 & 47 & 142 & 0 \\
$<3 \%$ of world GDP & 60 & 47 & 142 & 0 \\
$<4 \%$ of world GDP & 87 & 47 & 142 & 112 \\
\hline
\end{tabular}

Source: Authors' calculation.

Note: The exclusion threshold is applied to the GDP of the player (region in the model) and not to each country belonging to the region. IR is the set of scenarios where all players have no negative payoff (individual rationality constraints).

maximize equivalent variation, even the first threshold which excludes only small countries is efficient. The $\mathbf{1 5 1 0}$ outcome is adopted under bargaining weights based on economic size except when the interests of all zones with less than 4 percent of world GDP are excluded: the United States, the EU, and Japan are the only negotiators (these are the Triad countries) and s1551 should be chosen (see above). With democratic weights the outcome of trade negotiations is (1) s1530 for a 2 percent threshold; (2) s1230 for a 3 percent threshold; (3) s1511 for a 4 percent threshold. Democracy undermines the influence of the United States and the EU, while improving the position of Mediterranean countries.

From a global point of view, restricting negotiation to richer countries implies the adoption of a less harmonizing tariff reduction formula in agriculture. Moreover, when only Bangladesh does not participate in the bargaining process, an outcome may be reached under the equivalent variation criterion. Thus we find that the exclusion of WTO members is efficient. However, this is quite opposite to the essence of multilateralism. Excluding poorer countries/ regions is particularly inconsistent with the developmental objective of this round. Therefore, the following section addresses a more cooperative solution: the inception of side payments among countries/regions.

\section{Setting Up Side Payments}

In a cooperative framework a worldwide Pareto-optimum should be agreed on when countries/regions are allowed to redistribute the benefits obtained from trade liberalization. Setting up side payments provides a supplementary degree of freedom, and all outcomes are then feasible as long as total welfare increases. 
The "Aid for Trade" package cements this idea into a workable strategy (see Evenett 2005a). From an institutional point of view, these international transfers may take several shapes: aid for development, financing of facilities, adjustment packages (see the proposal of the International Monetary Fund's Anne Krueger in Cancun [Krueger 2003]). For example, various proposals have been put forth regarding the compensation of African-Caribbean-Pacific (ACP) countries for preference erosion as part of the tentative banana deal reached between Latin American producers, the EU, and the United States. Equivalent variation is the criterion that best fits these international financial transfers; for this reason we study implementation of side payments under this objective function.

From a mathematical point of view, the program of the cooperative game with side payments is defined by the equations:

$$
s^{*} \in \operatorname{Arg}_{s \in S} \operatorname{Max} G(s)=\prod_{m}\left(W^{m}(s)+T^{m}-W_{0}^{m}\right)^{\alpha_{m}}
$$

With: $W^{m}\left(s^{*}\right)+T^{m} \geq W_{0}^{m}, \forall m$

And: $\sum_{m} T^{m}=0$

$T^{m}$ represents the payments received/paid by $m$. The objective function to be maximized (equation 4 ) indicates that each country's real income variation, thanks to the trade reform, is augmented by the side payment when it is positive and is decreased when it is negative. Equation 5 expresses individual rationality and slightly differs from equation 2 as the side payment is included. Equation 6 means that the sum of the international transfers is balanced. It can be shown that the optimal solution is defined by

$$
W^{m}\left(s^{*}\right)+T^{m}-W_{0}^{m}=\alpha_{m} \cdot \sum_{m}\left(W^{m}\left(s^{*}\right)-W_{0}^{m}\right)
$$

At the optimum, a player should get a share $\alpha^{m}$-its bargaining power-of the total gain. If all players have the same power (the unweighted situation), the final distribution of gains has to be even. Otherwise, a player will use its veto power to block the outcome. Therefore the more uneven the initial distribution, the larger will be the redistribution.

The Nash bargaining game set-up describes a redistribution process on absolute level of gains. Therefore attributing the same bargaining power to different players will lead them to try to get the same share of the overall gain. But the same share represents very different outcomes in terms of relative gains. Adopting a weighting scheme that provides the same bargaining power to a big country and to a small one may be quite quixotic since an even distribution of absolute gains will lead to a very extreme distribution of relative 
gains. Using GDP weights allows us to correct for such a problem. However, a development-friendly outcome of the DDA may aim for the reduction of world inequalities; such a reduction entails that developing countries' gains should be more than proportional to their initial GDP. The "unweighted" and the "democratic" weighting schemes have such properties. When setting up side payments, the first-best solution to be agreed on is the one associated with the largest overall gain: s1531. It is the most ambitious scenario in terms of liberalization. When services are excluded from negotiation, the solution is $\mathrm{s} 0531$.

The total amount of side payments is shown in Table 3.8. Notably, the international transfers are very large. As discussed earlier, the more efficient the reform, the larger the global gain and the higher its dispersion. So in a sense these large transfers are due to the consensus rule and the right of veto given to each WTO member. They are much larger than the amount countries need to make up for their losses induced by the negotiated outcome: between 20 and 30 times larger. In fact, countries have to be compensated not only for losses (difference between equivalent variation implied by reform and initial equivalent variation) but also for not getting the average gain. These transfers add up to between 40 percent and 80 percent of total welfare gain, which represents a considerable financial payment. Moreover, the more power rich countries have, the smaller the transfers. For a similar reason, the "democratic" weighting scheme induces a large redistribution because most WTO members are small economies that have limited or no gains. The liberalization of services, by increasing the size of the cake, leads to more redistribution of gains except in the case of bargaining power based on economic size, due to the specific situation of the United States (see earlier).

Figure 3.2 shows the distribution of transfers under side payments. Services are included in the liberalization process and the Nash solution is defined with and without bargaining powers. This solution defines three net payers that are among the main beneficiaries from the liberalization process: the European Union, the European Free Trade Association (EFTA), and Japan. It is obviously related to a tariff structure with numerous peaks. Japan pays US $\$ 40$ billion to other countries upon a total gain of US $\$ 45$ billion. For some LDCs, side payments obtained are the only source of gain (Bangladesh and Africa south of the Sahara) and are quite significant (about 2.5 percent of the income of Africa south of the Sahara). The GDP-weighted case is obviously more advantageous for rich countries. For example, the EU does not pay anything, and Japan's payment is reduced by about 25 percent. The United States benefits from large payments (US\$34 billion). Previously, countries' 
TABLE 3.8 Nash solutions with side payments (US\$ billions)

\begin{tabular}{lccc}
\hline Global transfers & Unweighted & Democratic & $\begin{array}{c}\text { Economic } \\
\text { weights (GDP) }\end{array}$ \\
\hline With liberalization in services & 66.4 & 80.7 & 44.0 \\
Without liberalization in services & 63.2 & 78.8 & 44.1 \\
\hline
\end{tabular}

Source: Authors' calculation.

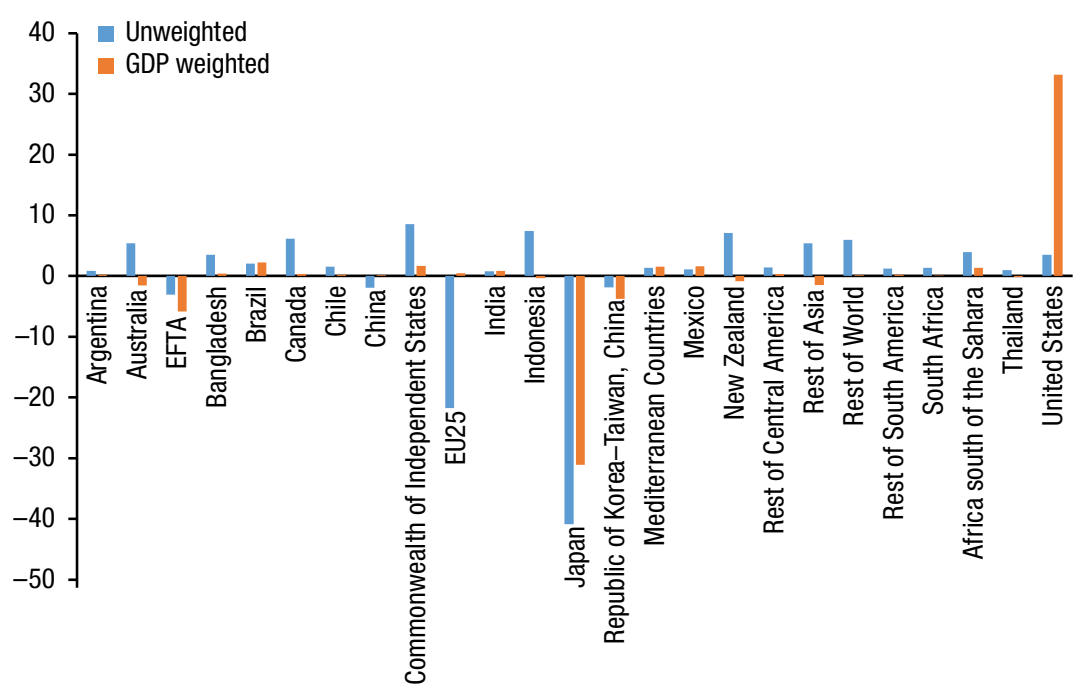

Source: Authors' calculation.

Note: EFTA = European Free Trade Association; EU25 = European Union 25 countries.

The most ambitious scenario is the optimal outcome with transfers (s1531) when transfers are allowed. A negative transfer is a payment done, a positive one is a payment received.

gain did not reflect their economic size. When services are excluded, the profile of the distribution is similar. But larger side payments received by the United States are noteworthy due to its gains related to trade liberalization in services.

\section{Extending the Domain of Negotiation}

Another possible solution is to extend the domain of the negotiation. For example, the introduction of the Singapore issues, such as trade facilitation, or 
more generally, the inclusion of services in the negotiation might be viewed as an extension of the domain of negotiation: countries that lose due to the liberalization of agriculture and industry could offset these losses by gains from the liberalization of this sector. As it is not possible to extend the domain of negotiation from the situation depicted in the previous sections, we consider a restriction of this domain and evaluate the IR-set of the game when the negotiation takes place either only in agriculture, or only in industry, or only in services, or only about export subsidies.

Results are illustrated on Table 3.9. For each criterion (Equivalent variation/Real GDP/Terms of trade), we indicate the number of scenarios in the set of feasible issues (column Domain), then the number of scenarios in the IR-set (column IR-set). Since a negotiation between all players gives birth to a quasi-stalemate when players maximize equivalent variation (the IR-set consists of only the liberalization of services), and complete stalemate when the objective is terms of trade, we also consider an exclusion of countries/zones representing less than 2 percent of the world GDP, and then a situation where countries/zones of which GDP is less than 4 percent of the world GDP are excluded. For example, when the objective is equivalent variation and in the case of an exclusion of countries/zones of less than 2 percent of world GDP, a negotiation in all dimensions is especially beneficial as the IR-set consists of 59 potential agreements instead of 0 if the negotiation takes place only in agriculture or industry.

It appears from Table 3.9 that an extension of the domain of negotiation systematically increases the number of trade reforms that countries can potentially agree on. The agricultural sector appears once again at the cornerstone of the trade negotiations. Whatever the negotiators' objective is and in any scheme of country participation (all players/exclusion at 2 percent of world GDP/exclusion at 4 percent of world GDP), it is impossible to find a solution other than the status quo if a negotiation takes place only in agriculture: the IR-set of the game is systematically empty.

\section{Analyzing Coalitions}

Since 1995, the functioning of WTO is clearly affected by coalitions whose life span is more or less long and whose raison d'être is not evident. The G20 case clearly illustrates this point. This coalition gathers countries with heterogeneous trade characteristics. In this context it is useful to examine the role and the impact of such coalitions. We suppose that a coalition is justified when small players have been excluded from a negotiation and form a 
TABLE 3.9 Impact of an extension of the negotiation domain (IR)

\begin{tabular}{|c|c|c|c|c|}
\hline \multirow[b]{2}{*}{ Criteria } & \multirow[b]{2}{*}{ Domain } & \multicolumn{3}{|c|}{ IR-set } \\
\hline & & All players & $\begin{array}{l}\text { Exclusion at } 2 \% \\
\text { of world GDP }\end{array}$ & $\begin{array}{c}\text { Exclusion at } 4 \% \\
\text { of world GDP }\end{array}$ \\
\hline \multicolumn{5}{|c|}{ Equivalent variation } \\
\hline Services & 1 & 1 & 1 & 1 \\
\hline Industry & 5 & 0 & 0 & 5 \\
\hline Agriculture & 5 & 0 & 0 & 0 \\
\hline Export subsidies & 1 & 0 & 0 & 1 \\
\hline All dimensions & 143 & 1 & 59 & 87 \\
\hline \multicolumn{5}{|l|}{ Real GDP } \\
\hline Services & 1 & 1 & 1 & 1 \\
\hline Industry & 5 & 5 & 5 & 5 \\
\hline Agriculture & 5 & 0 & 0 & 0 \\
\hline Export subsidies & 1 & 1 & 1 & 1 \\
\hline All dimensions & 143 & 47 & 47 & 47 \\
\hline \multicolumn{5}{|l|}{ Terms of trade } \\
\hline Services & 1 & 0 & 0 & 0 \\
\hline Industry & 5 & 0 & 0 & 2 \\
\hline Agriculture & 5 & 0 & 0 & 0 \\
\hline Exports subsidies & 1 & 0 & 0 & 1 \\
\hline All dimensions & 143 & 0 & 0 & 112 \\
\hline
\end{tabular}

Source: Authors' calculation.

Note: The results for the "all dimensions" rows mimic the information of Table 3.7. IR is the set of scenarios where all players have non-negative payoff (individual rationality constraints).

coalition as a means to continue participating. The presence of small countries/regions in a negotiation that is supposedly taking place only among large countries deeply affects the cooperative game. To exemplify this, we examine the situation in which a 4 percent threshold has been applied; in this case, if no coalition is introduced, the Nash solution is determined by taking into account only gains for the Triad countries (that is, the United States, the EU, and Japan).

Numerous coalitions of countries appeared during the eight years of the Doha negotiations. Among them, the G90, G20, and G10 have been especially effective and are studied herein. Assuming that each WTO country has veto power under the principle of unanimity, it is difficult to justify the appearance of coalitions. However, we feel that coalitions allow small countries to gather in order to participate in negotiations from which they would otherwise be 
excluded. As far as the consequences of coalition formation, we compare the gain obtained by each country/region in the presence and absence of a coalition. For a country/region, participation in the coalition implies that its interests are taken into account, while such interests are not accounted for in the absence of the coalition, because the formation of this coalition entails a change in the set of agreeable reforms and in the solution of the cooperative game. Moreover, we assume that the bargaining power of a coalition equals the sum of its members' bargaining powers. 'Table 3.10 through Table 3.13 show these comparisons for different countries/regions in different game configurations - that is, with or without other coalitions, with or without bargaining power.

Table 3.10 provides the results for the G10 coalition, which provides gains to all its members. The situation of Japan is strongly improved (+US $\$ 44$ billion) when the other G10 members' participation constraints are introduced, especially in case of GDP weights. The G10 is worthwhile for its members only if they have to face the United States and the EU. In the presence of other coalitions (G20 and G90), the G10 does not manage to influence the final outcome of the game.

The situation for G20 members is displayed in Table 3.11. This coalition improves the welfare of all of its members, especially when bargaining powers are based on GDP size. In this case, seven of the ten G20 countries/regions modeled herein move from net losses to net gains when we switch from the s1551 (weighted case) outcome selected by the Triad to the 1210 situation. ${ }^{10}$ In the s1210 situation, NAMA liberalization is limited, SDT is introduced, and the AMA tariff reduction is deepened with a moderate Swiss formula coefficient instead of the linear formula chosen by the Triad. In the presence of the G10, the G20 still has incentives to appear. In all configurations, India benefits the most from the G20 implementation. However, the presence of the G90 eliminates the incentives for the G20 to appear. Indeed, the G90 allows small economies to step back in the arena and enforce their participation constraints; they empty the core of the game, meaning that there is only one possible outcome (that is, s1000, which is either the status quo or the unique liberalization of services, depending on the possibility of negotiating in this sector). The presence or absence of other players cannot modify the outcome.

\footnotetext{
9 An existing coalition with the sum of its members' GDP shares larger than the fixed threshold uses its right of veto as long as the individual rationality of each of its members is not satisfied.

10 We consider that $\mathrm{s} 1551$ is the scenario closest to the US-EU agreement that preceded the Cancun meeting.
} 
TABLE 3.10 Effects of the apparition of the G10 coalition on its members (US\$ billions)

\begin{tabular}{lccc}
\hline Country & Unweighted & $\begin{array}{c}\text { GDP } \\
\text { weights }\end{array}$ & $\begin{array}{c}\text { Democratic } \\
\text { weights }\end{array}$ \\
\hline EFTA (European Free Trade Association) & 0 & 4.6 & 0.3 \\
Japan & 0 & 44.4 & 1.2 \\
Republic of Korea-Taiwan & 0 & 4.2 & 0.2 \\
\hline
\end{tabular}

Source: Authors' calculation.

Note: $\mathrm{G} 10=\mathrm{A}$ group of 10 countries mainly from the Organisation for Economic Co-operation and Development (OECD), including Japan, the Republic of Korea, and Taiwan, China. This table represents the change in real income for the different members of the G10 if this coalition appears. The exclusion threshold is set to 4 percent of world GDP, thus the reference situation is the case where only the United States, the EU, and Japan participate in the negotiations. The presence of the G90 and/or G20 does not allow the G10 to modify the outcome of the game and these cases are not represented here.

TABLE 3.11 Effects of the apparition of the G20 coalition on its members (US\$ billions)

\begin{tabular}{|c|c|c|c|c|c|c|}
\hline \multirow[b]{2}{*}{ Country or Region } & \multicolumn{3}{|c|}{$\begin{array}{c}\text { G20 facing the Triad } \\
\text { (United States, EU, Japan) }\end{array}$} & \multicolumn{3}{|c|}{ G20 facing the Triad and the G10 } \\
\hline & Unweighted & $\begin{array}{c}\text { GDP } \\
\text { weights }\end{array}$ & $\begin{array}{l}\text { Democratic } \\
\text { weights }\end{array}$ & Unweighted & $\begin{array}{c}\text { GDP } \\
\text { weights }\end{array}$ & $\begin{array}{c}\text { Democratic } \\
\text { weights }\end{array}$ \\
\hline Argentina & 0.6 & 1.0 & 0.6 & 0.6 & 0.4 & 0.4 \\
\hline Brazil & 0.9 & 0.8 & 0.9 & 0.9 & 0.9 & 0.9 \\
\hline Chile & 0.1 & 0.1 & 0.1 & 0.1 & 0.1 & 0.1 \\
\hline China & 1.1 & 3.9 & 1.1 & 1.1 & 0.8 & 0.8 \\
\hline India & 1.6 & 3.6 & 1.6 & 1.6 & 1.0 & 1.1 \\
\hline Mexico & 1.4 & 2.5 & 1.4 & 1.4 & 1.0 & 1.0 \\
\hline Rest of Central America & 0.1 & 0.3 & 0.1 & 0.1 & 0.1 & 0.1 \\
\hline Rest of South America & 0.2 & 0.5 & 0.2 & 0.2 & 0.1 & 0.2 \\
\hline South Africa & 0.1 & 0.3 & 0.1 & 0.1 & 0.1 & 0.1 \\
\hline Thailand & 0.1 & 0.3 & 0.1 & 0.1 & 0.1 & 0.1 \\
\hline
\end{tabular}

Source: Authors' calculation.

Note: $\mathrm{G} 10=\mathrm{A}$ group of 10 countries mainly from the Organisation for Economic Co-operation and Development (OECD), including Japan, the Republic of Korea, and Taiwan, China; G20 = A group of 20 emerging countries and least developed countries that is led by Brazil and India and also includes China and South Africa. This table represents the change in real income for the different members of the G20 if this coalition appears. The exclusion threshold is set to 4 percent of world GDP. The presence of the G90, a group of 90 poor countries, does not allow the G20 to modify the outcome of the game and this case is not represented here. Figures in bold indicate countries that move from losses to positive gains with the implementation of the coalition. 
TABLE 3.12 Effects on G90 coalition for its members of other coalitions (US\$ billions)

\begin{tabular}{lccc}
\hline G90 facing other coalition & Bangladesh & $\begin{array}{c}\text { Mediterranean } \\
\text { countries }\end{array}$ & $\begin{array}{c}\text { Africa south of } \\
\text { the Sahara }\end{array}$ \\
\hline Triad & $\mathbf{0 . 3}$ & -1.3 & $\mathbf{1 . 1}$ \\
Unweighted & $\mathbf{0 . 3}$ & 0.8 & $\mathbf{1 . 5}$ \\
GDP weighted & $\mathbf{0 . 3}$ & -1.3 & $\mathbf{1 . 1}$ \\
Democratic weights & & & \\
Triad + G10 & $\mathbf{0 . 3}$ & -1.3 & $\mathbf{1 . 1}$ \\
Unweighted & $\mathbf{0 . 3}$ & -1.7 & $\mathbf{0 . 9}$ \\
GDP weighted & $\mathbf{0 . 3}$ & -1.6 & $\mathbf{1 . 0}$ \\
Democratic weights & & & \\
Triad + G20 & $\mathbf{0 . 2}$ & -2.5 & $\mathbf{0 . 6}$ \\
Unweighted & $\mathbf{0 . 3}$ & -2.3 & $\mathbf{0 . 7}$ \\
GDP weighted & $\mathbf{0 . 2}$ & -2.5 & $\mathbf{0 . 6}$ \\
Democratic weights & & & \\
Triad + G10 + G20 & & -2.5 & $\mathbf{0 . 6}$ \\
Unweighted & $\mathbf{0 . 2}$ & -2.3 & $\mathbf{0 . 7}$ \\
GDP weighted & $\mathbf{0 . 3}$ & -2.5 & $\mathbf{0 . 6}$ \\
Democratic weights & $\mathbf{0 . 2}$ & &
\end{tabular}

Source: Authors' calculation.

Note: $\mathrm{G} 90=\mathrm{A}$ group of 90 poor countries with a more defensive trade strategy aimed to advance pro-poor policies (most African countries are members of this group). This table represents the change in real income for the different members of the G90 if this coalition appears. The exclusion threshold is set to 4 percent of world GDP. South Africa is not represented here but the existence of the G90 always reduces its gains. Figures in bold indicate countries that move from losses to positive gains with the implementation of the coalition.

The G90 (Table 3.12) is the most interesting coalition. By allowing Bangladesh to reenter the negotiation, the presence of this coalition empties the core of the game. The G90 improves the situation of both African countries south of the Sahara and Bangladesh by maintaining the status quo. For the Mediterranean countries, in contrast, status quo in AMA and NAMA is not the best outcome. These countries would prefer a liberalization scheme that is agreed upon by the largest players. For this reason the G90 brings them net losses. Finally, the G90 is never useful for South Africa; this country is always better off when playing with the G20. These two last remarks illustrate the heterogeneity of the interests inside the G90 coalition. We conclude by looking at the consequences for the EU and US gains of the implementation of these different coalitions (Table 3.13). As expected, in most situations, 
TABLE 3.13 Effects of the coalitions on the EU and US gains (US\$ billions)

\begin{tabular}{lrrrrrrrr}
\hline & \multicolumn{2}{c}{ Unweighted } & & \multicolumn{2}{c}{ GDP weights } & & \multicolumn{2}{c}{ Democratic weights } \\
\cline { 2 - 3 } Game configuration & EU25 & US & & EU25 & US & & EU25 & US \\
\hline Triad + G10 & 0.0 & 0.0 & & 1.9 & -2.8 & & 1.4 & -0.4 \\
Triad + G20 & -11.4 & -2.0 & & -3.0 & -5.1 & & -11.4 & -2.0 \\
Triad + G90 & -27.5 & 0.1 & & -18.3 & -3.3 & -27.5 & 0.1 \\
Triad + G10 + G20 & -11.4 & -2.0 & & -3.0 & -5.1 & -11.4 & -2.0 \\
Triad + G10 + G90 & -27.5 & 0.1 & & -18.3 & -3.3 & & -27.5 & 0.1 \\
Triad + G20 + G90 & -27.5 & 0.1 & & -18.3 & -3.3 & -27.5 & 0.1 \\
Triad + G10 + G20 + G90 & -27.5 & 0.1 & -18.3 & -3.3 & -27.5 & 0.1 \\
\hline
\end{tabular}

Source: Authors' calculation.

Note: EU25 = European Union 25 countries; the Triad is composed of the EU, the United States, and Japan-the three countries for which GDP is above 4 percent of world GDP; 4 percent of world GDP is the threshold we have chosen for participating in the negotiations. The reference situation is the scenario when only the Triad participates in the negotiations.

the gains of the two major players are negatively impacted by the formation of counterpowers.

\section{Conclusion}

In this chapter the simultaneous use of CGE analysis and game theory allows us to explain some strategic features of the DDA trade negotiations. In particular, we see that AMA talks play a crucial role: they increase the overall gain but also reduce the inequalities driven by NAMA liberalization. Simultaneously, trade negotiation cannot take place if only liberalization in agriculture is negotiated, as the core of the game would be empty. Moreover, the adoption of tariff-harmonizing formulae (more cuts in higher import tariffs) leads to greatly increased global gains. Finally, the dramatic complexity in the current structure of protection and market access convincingly explains why trade negotiations are so difficult today. Thus it does not seem surprising that our game-theoretic CGE approach concludes with a rather pessimistic statement: the Nash solution is often the status quo.

Obviously, the number of negotiating members adds constraints to the bargaining program. We show that the exclusion of countries/regions with GDPs below a certain threshold drastically improves the efficiency of the negotiation process, regardless of the governments' objective. We also demonstrate that the formation of coalitions is a potential means through which developing countries/regions may block solutions imposed by rich countries/regions. The G20 coalition is successful with the inclusion of the SDT clause and with 
less liberalization of the industrial sector. Moreover, the G10 is always beneficial for its members. We also consider the expansion of the domain of trade negotiation. Negotiating in services, industry, and agriculture is more efficient than negotiating in only industry and agriculture, which is itself more efficient than negotiating in agriculture alone. Side payments may also be a workable solution, as they allow large agents to maximize the size of the cake, while compensating losers. When we implement a cooperative solution of the game with side payments, we find that these international payments represent a significant share of global income gain. Notably, however, in one solution side payments are used to remunerate very rich countries/regions (for example, the United States). Both characteristics of this cooperative solution make it implausible.

An illustration of the realistic aspect of our conclusions is that previously WTO Director-General Pascal Lamy combined the three solutions that we propose herein, in the hopes of breaking the stalemate: (1) He has sought to expand the coverage of the negotiations. We feel that more could be done in this regard, especially with the inclusion of the Singapore issues. ${ }^{11}$ (2) He has tried to reach an agreement between a limited number of WTO members (most of the WTO Geneva meetings in July 2008 took place among seven countries). (3) He has sought to implement side payments ("Aid for Trade" can be interpreted along these lines). There may be other means to compensate for losses related to erosion of preferences, such as granting new preferences (for example, see the duty-free quota-free regime given by rich countries to LDCs at the Hong Kong Ministerial). Given the complexity of the current trade and protection structures, negotiators must be highly creative when designing a final trade agreement that could be accepted by all WTO members.

\section{Bibliography}

Bagwell, K., and R. Staiger. 1999. "An Economic Theory of GATT.” American Economic Review 89: 215-248.

- 2002. The Economics of the World Trading System. Boston, MA, US: Massachusetts Institute of Technology Press.

Baldwin, R., and R. Clarke. 1988. "Game Modeling Multilateral Trade Negotiations.” Journal of Policy Modeling 9 (2): 257-284.

11 The Singapore issues (trade and investment, trade and competition policy, transparency in government procurement, and trade facilitation) were introduced to the WTO agenda at the December 1996 Ministerial Conference in Singapore. 
Bchir, M., L. Fontagné, and S. Jean. 2005. From Bound Duties to Actual Protection: Industrial Liberalisation in the Doha Round. CEPII Working Papers 2005-12. Paris: CEPII (Centre d'Etudes Prospectives et d'Informations Internationales).

Bchir, M., S. Jean, and D. Laborde. 2006. “Binding Overhang and Tariff-Cutting Formulas.” Review of World Economics 142 (2): 207-232.

Bouët, A., Y. Decreux, L. Fontagné, S. Jean, and D. Laborde. 2008. "Assessing Applied Protection across the World." Review of International Economics 16 (5): 850-863.

Bouët, A., and D. Laborde. 2010. “Assessing the Potential Cost of a Failed Doha Round.” World Trade Review 9: 319-351.

CEPII (Centre d'Etudes Prospectives et d'Informations Internationales). 2001. "Chelem on the Net." Accessed 2001. www.cepii.fr/anglaisgraph/bdd/chelem.htm.

Decreux, Y., and H. Valin. 2007. MIRAGE, Updated Version of the Model for Trade Policy Analysis Focus on Agriculture and Dynamics. CEPII Working Paper 2007-15. October. Paris: Centre d'Etudes Prospectives et d'Informations Internationales.

Dimaranan, B. V., and R. A. McDougall. 2005. Global Trade, Assistance, and Production: The GTAP 6 DataBase. Center for Global Trade Analysis. West Lafayette, IN, US: Purdue University.

Economist. 2008. "So Near and Yet So Far." May 8.

Evenett, S. J. 2005a. “From 'Trade versus Aid' to 'Aid for Trade'?” Accessed 2008. https://www .alexandria.unisg.ch/22674/1/EvenettWTOnews2September2005.pdf.

—. 2005b. "Some Tough Love on 'Aid for Trade." Intereconomics 40 (6): 326-329.

Francois, J., and B. Hoekman. 1999. Market Access in the Service Sectors. Amsterdam: Tinbergen Institute.

Francois, J., H. van Meijl, and F. van Tongeren. 2005. "Trade Liberalization in the Doha Development Round." Economic Policy 20 (42): 349-391.

Grossman, G., and E. Helpman. 1995. “Trade Wars and Trade Talks.” Journal of Political Economy 103: $675-708$.

Hertel, T. W., and R. Keeney. 2006. "Assessing the Impact of WTO Reforms on World Agricultural Markets: A New Approach." In Agricultural Commodity Markets and Trade: New Approaches to Analyzing Market Structure and Instability, edited by A. Sarris and D. Hallam, 402425. Rome: FAO (Food and Agriculture Organization of the United Nations), Edward Elgar.

Hoekman, B. 1996. “Assessing the General Agreement on Trade in Services." In The Uruguay Round and the Developing Countries, edited by W. Martin and A. Winters, 88124. Cambridge, UK: Cambridge University Press for the World Bank.

Johnson, H. 1953. “Optimum Tariffs and Retaliation.” Review of Economic Studies 21 (2): 142-153. 
1965. "An Economic Theory of Protectionism, Tariff Bargaining, and the Formation of Customs Unions." Journal of Political Economy 73 (3): 256-283.

Kalai, E., and M. Smorodinsky. 1975. “Other Solutions to Nash's Bargaining Problem.” Econometrica 43 (3): 513-518.

Kalirajan, K., G. McGuire, D. Nguyen-Hong, and M. Schuele. 2000. "The Price Impact of Restrictions on Banking Services." In Impediments to Trade in Services: Measurement and Policy Implications, edited by C. Findlay and T. Warre, 215-230. London and New York: Routledge.

Krueger, A. 2003. Speech presented at the Fifth WTO Ministerial Conference, Cancun, September 10. Accessed 2004. www.imf.org/external/np/speeches/2003/091003.htm.

Mas-Colell, A., M. Whinston, and J. Green. 1995. Microeconomic Theory. New York: Oxford University Press.

Mayer, W. 1981. "Theoretical Considerations on Negotiated Tariff Adjustments." Oxford Economic Papers 33 (1): 135-153.

Messerlin, P. 1995. La Nouvelle Organisation Mondiale du Commerce. Paris: Dunod.

Nash, J. 1953. “Two-person Cooperative Games.” Econometrica 21 (1): 128-140.

Riezman, R. 1982. “Tariff Retaliation from a Strategic Viewpoint.” Southern Economic Journal 48 (3): $583-593$.

Shapley, L. 1953. "A Value for N-Person Games." In The Shapley Value: Essays in Honor of Lloyd S. Shapley, edited by A. Roth, 307-317. London: Cambridge University Press.

Stiglitz, J., and A. Charlton. 2006. "Aid for Trade: A Report for the Commonwealth Secretariat." Columbia University Academic Commons. Accessed February 22, 2017. https://academic commons.columbia.edu/catalog/ac:126953.

Trewin, R. 2000. "A Price-Impact Measure of Impediments to Trade in Telecommunications Services." In Impediments to Trade in Services: Measurement and Policy Implications, edited by C. Findlay and T. Warre, 101-118. London and New York: Routledge.

Tyers, R. 1990. "Implicit Policy Preferences and the Assessment of Negotiable Trade Policy Reforms." European Economic Review 34 (7): 1399-1426.

van Tongeren, F., H. van Meijl, and Y. Surry. 2001. "Global Models Applied to Agricultural and Trade Policies: A Review and Assessment.” Agricultural Economics 26 (2): 149-172.

Van der Mensbrugghe, D., and J. Beghin. 2004. Global Agricultural Liberalization: An In-depth Assessment of What Is at Stake. CARD Working Paper. Ames, IA, US: Center for Agricultural and Rural Development, Iowa State University.

WTO (World Trade Organization). 2004. “The Doha Declaration Explained.” Accessed 2004. https://www.wto.org/english/tratop_e/dda_e/dohaexplained_e.htm. 